\title{
High dose inhaled atrial natriuretic peptide is a bronchodilator in asthmatic subjects
}

\author{
G. Hulks, N.C. Thomson
}

High dose inhaled atrial natriuretic peptide is a bronchodilator in asthmatic subjects. G. Hulks, N.C. Thomson. CERS Journals Ltd 1994.

ABSTRACT: Atrial natriuretic peptide (ANP) has been shown to be an effective bronchodilator when given intravenously, but its efficacy by inhalation has not been assessed.

In the first part of the current study, six asthmatic subjects, mean (SEM) forced expiratory volume in one second $\left(\mathrm{FEV}_{1}\right) 2.09(0.30) l$, received 0.1 and $1 \mathrm{mg}$ atrial natriuretic peptide by inhalation, and in the second study five subjects, FEV 1.92 (0.40) $l$, received $5 \mathrm{mg}$ ANP by inhalation. ANP was given in a placebo-controlled, double blind, randomized manner, with measurement of $\mathrm{FEV}_{1}$ over the following $60 \mathrm{~min}$. Nebulized salbutamol was given at $60 \mathrm{~min}$ as a measure of the maximal bronchodilator response attainable by conventional therapy.

No significant bronchodilator effect was seen following the 0.1 or $1 \mathrm{mg}$ inhalation, although the latter produced a minimal transient elevation in peripheral atrial natriuretic peptide plasma levels. A bronchodilator effect was seen with the $5 \mathrm{mg}$ dose, which produced $\Delta \mathrm{FEV} \mathrm{V}_{1} 0.42(0.09) l$ compared to $0.93(0.13) l$ subsequently produced by salbutamol. This effect peaked at 5 min and was no different from placebo from 10 min onwards

We conclude that atrial natriuretic peptide may produce significant bronchodilation when given by inhalation in high doses, and speculate that substances which generate cyclic guanosine monophosphate (cGMP) in airway smooth muscle warrant further investigation as potential bronchodilatory agents.

Eur Respir J., 1994, 7, 1593-1597.

Atrial natriuretic peptide (ANP) is known to be released from the cardiac atria in response to stretch, and the biologically active form circulates in man as a 28 amino acid peptide, having diverse effects on volume and pressor homeostasis. Perhaps because ANP is secreted from the heart, most attention has been focused on its cardiovascular and renal effects. However, autoradiography has identified ANP in animal airway smooth muscle [1], and ANP messenger ribonucleic acid (mRNA) has also been found in the lung [2], suggesting that ANP of pulmonary origin may have a local autocrine effect or may contribute to circulating plasma levels. The lung has also emerged as an important site of breakdown of circulating ANP [3], a role previously thought to be largely reserved for the kidneys

We, and others, have shown that the intravenous infusion of ANP has a dose-dependent bronchodilatory effect in the constricted (asthmatic) human airway [4-6], and it is speculated that the mechanism of this effect may be directly via relaxation of bronchial smooth muscle, although this has yet to be proven.

One early animal study examined the effect of ANP given by inhalation, and this failed to show any bronchodilatation or any protection against induced bronchoconstriction in the guinea-pig [7]. The inhaled dose was very small relative to the intravenous dose employed,
Dept of Respiratory Medicine, Western Infirmary, Glasgow, UK.

\section{Correspondence: N.C. Thomson}

Dept of Respiratory Medicine

Western Infirmary

Glasgow

G11 6NT

UK

Keywords: Asthma

atrial natriuretic peptide

bronchodilation

cyclic guanosine monophosphate

Received: November 151993

Accepted after revision May 121994 and the peptide used was a synthetic 26 amino acid ANP fragment (8-33 C-terminal acid), which differs both in size and structure from the human form $\alpha$-hANP (1-28). However, we have subsequently shown that inhaled ANP is able to exert a very significant protective effect against histamine and methacholine challenge in the hyperreactive airway $[8,9]$.

The purpose of the current study was to examine the possible bronchodilatory effect of ANP when given by inhalation to the constricted human airway, and to determine any change in circulating plasma levels so produced. The effect was compared with nebulized salbutamol as the "gold standard" bronchodilatory effect attainable by conventional therapy.

\section{Material and methods}

\section{Study subjects}

Subject details are given in table 1. All subjects were nonsmokers and had previously demonstrated $\geq 25 \%$ reversibility to inhaled salbutamol $(2.5 \mathrm{mg})$ at a preenrolment screening visit. All subjects gave written informed consent to the protocol, which was approved by the Glasgow West Ethics Committee. 
Table 1. - Subject details (Study 1 included subjects Nos. 1-6, Study 2 included subjects Nos. 1, 2, 6-8)

\begin{tabular}{ccccccl}
\hline $\begin{array}{l}\text { Sub. } \\
\text { No. }\end{array}$ & $\begin{array}{c}\text { Sex } \\
\text { yrs }\end{array}$ & Age & $\begin{array}{c}\mathrm{FEV}_{1} \\
l\end{array}$ & $\begin{array}{c}\mathrm{FEV}_{1} \\
\% \text { pred }\end{array}$ & $\begin{array}{c}\text { Atopic } \\
\text { status }\end{array}$ & Medication \\
\hline 1 & M & 30 & 2.16 & 54 & + & S, SCG \\
2 & M & 20 & 2.96 & 68 & + & S, HBD \\
3 & F & 39 & 1.20 & 48 & - & S, HBD, SRS \\
4 & M & 28 & 2.84 & 65 & + & S, HBD \\
5 & M & 27 & 2.00 & 44 & - & S, HBD \\
6 & M & 55 & 1.37 & 48 & - & S, HBD, OC \\
7 & M & 39 & 1.68 & 51 & + & S, LBD, IB \\
8 & F & 36 & 1.37 & 54 & + & S, LBD, SRS \\
\hline
\end{tabular}

$\mathrm{FEV}_{1}$ : forced expiratory volume in one second; $S$ : salbutamol (inhaled); LBD: low-dose beclomethasone dipropionate $\left(<800 \mu \mathrm{g} \cdot\right.$ day $\left.^{-1}\right)$; HBD: high-dose beclomethasone dipropionate $\left(>800 \mu \mathrm{g} \cdot \mathrm{day}^{-1}\right)$; SCG: sodium cromoglycate; SRS: sustained release salbutamol (oral); OC: oral corticosteroids; IB: ipratropium bromide; +: positive; -: negative.

\section{Study design}

Two studies are reported, in which the methodology was similar and which employed some overlap of subjects. Constricted asthmatic subjects were given various doses of inhaled ANP $(0.1,1$ and $5 \mathrm{mg})$ in a randomized, double-blind, placebo-controlled protocol. Forced expiratory volume in one second $\left(\mathrm{FEV}_{1}\right)$ was recorded over 60 min following ANP and compared with the subsequent response to inhaled salbutamol.

Measurements. $\mathrm{FEV}_{1}$; dry wedge spirometer (Vitalograph S, Vitalograph Ltd, Buckingham, UK). The best of three attempts was used for analysis, except at 2 min postANP when the best of two technically satisfactory recordings was accepted owing to constraints of time.

Pulse/blood pressure; automatic sphygmomanometer (EME Auto BP Monitor, EME Ltd, Brighton, UK) with the mean of two values at each time-point used for analysis.

ANP; $5 \mathrm{ml}$ venous blood taken into prechilled potassium ethylenediamine tetra-acetic acid (EDTA) tubes containing 1,000 kallikrein inhibitory units aprotinin (Bayer, Newbury, Bucks, UK) and spun within $90 \mathrm{~min}$. Following extraction of plasma on $\mathrm{C}-18$ reverse phase columns (Sep-Pak; Waters Assoc., Milford, MA, USA), peptide was subsequently measured by established radioimmunoassay [10]. Inter- and intra-assay variation was consistently less than $10 \%$.

Catecholamines; $5 \mathrm{ml}$ venous blood taken into prechilled lithium-heparin tubes and spun within $90 \mathrm{~min}$. Catecholamines were subsequently measured by established radioenzymatic assay [11]. The limit of detection was $0.1 \mathrm{nmol} \cdot l^{-1}$ for both epinephrine and norepinephrine, and the inter- and intra-assay variation was $\leq 10 \%$.

\section{Methods}

Study 1. Six subjects (Nos. 1-6) were studied (table 1), with mean (SEM) age 33 (5) yrs and baseline FEV 2.09 (0.30) $l$, equivalent to 54 (4)\% predicted; this value did not vary significantly between study days. Subjects attended at the same time of day, on three separate occasions at least 5 days apart. Inhaled bronchodilator therapy was discontinued for $8 \mathrm{~h}$ and oral bronchodilators for $24 \mathrm{~h}$; sodium cromoglycate, inhaled corticosteroids and oral corticosteroids were continued as usual. Twenty minutes after insertion of an intravenous cannula, baseline recordings were made of plasma ANP and catecholamines, pulse/blood pressure and $\mathrm{FEV}_{1}$. Thereafter, either ANP or placebo was given by inhalation in a randomized, double-blind manner, with doses of ANP corresponding to 0.1 or $1 \mathrm{mg}$. All measurements were repeated at 2, 5, 10, 20,30, 40, 50 and $60 \mathrm{~min}$ after inhalation; and, after the $60 \mathrm{~min}$ evaluation, $2.5 \mathrm{mg}$ nebulized salbutamol was given to assess the full degree of reversibility attainable. Final recordings were taken 20 min after salbutamol.

Study 2. The second study was devised after the results of Study 1 had been analysed. Five subjects (Nos. 1, 2, 6-8) were studied (table 1), with mean age 36 (6) yrs, baseline $\mathrm{FEV}_{1} 1.92(0.40) l$ on the placebo day and 1.90 (0.42) $l$ on the day of active inhalation (NS). The study design was exactly the same as in Study 1, with the exception that only two visits were required when subjects received either placebo or $5 \mathrm{mg}$ inhaled ANP, again in randomized, double-blind manner.

Administration of peptide. Because of the expense of ANP, especially in the higher doses ( $£ 750$ per patient) it was felt important to minimize wastage during aerosolization, and consequently a Mizer aerosol conservation device was employed (Medic-aid, Pagham, Sussex, UK). Studies using radiolabelled nebulisate have demonstrated approximately a twofold increase in pulmonary deposition of drugs aerosolized in this manner [12]. A Microneb III nebulizer (Lifecare Hospital Supplies Ltd, Market-Harborough, UK) with a fill volume of $3.5 \mathrm{ml}$ was employed, and it was established that, when driven by compressed air at 50 psi with a flow rate of 10 $l \cdot \mathrm{min}^{-1}$, nebulization to "dryness" took approximately 8 min and left a residual volume of $\sim 0.9 \mathrm{ml}$.

Drugs. $\alpha$-human ANP (1-28) (Bachem, Saffron Walden, UK); ANP was made up in $3.5 \mathrm{ml}$ sterile saline $(0.9 \%)$. Placebo inhalation consisted of $3.5 \mathrm{ml}$ sterile saline alone. All trial ampoules were stored at $-70^{\circ} \mathrm{C}$ and our own inhouse quality control confirmed that there was no loss of potency of ANP over at least three months stored under these conditions.

Salbutamol (Ventolin nebulizer solution; Allen \& Hanburys Ltd, Middlesex, UK); $2.5 \mathrm{mg}$ administered via Medix Compact AC nebulizer (Medix Ltd, Lutterworth, Leicestershire, UK).

\section{Analysis}

Baseline $\mathrm{FEV}_{1}$ and ANP values between study days were compared using Student's t-test for paired values. The changes in $\mathrm{FEV}_{1}$ and in circulating levels of ANP after inhalation were compared by analysis of variance. In all cases, a p-value $<0.05$ was taken to be significant. 
Table 2. - Study $1(\mathrm{n}=6)$. Mean (SEM) plasma atrial natriuretic peptide (ANP) and $\Delta \mathrm{FEV}_{1}$ in response to inhalation of 0.1 and $1 \mathrm{mg}$ ANP

\begin{tabular}{|c|c|c|c|c|c|c|}
\hline \multirow{2}{*}{$\begin{array}{l}\text { Time } \\
\text { min }\end{array}$} & \multicolumn{3}{|c|}{ Plasma ANP $\mathrm{pg} \cdot \mathrm{ml}^{-1}$} & \multicolumn{3}{|c|}{$\Delta \mathrm{FEV}_{1} l$} \\
\hline & Placebo & $0.1 \mathrm{mg}$ ANP & $1 \mathrm{mg}$ ANP & Placebo & $0.1 \mathrm{mg}$ ANP & $1 \mathrm{mg}$ ANP \\
\hline Baseline & $17(3)$ & $15(3)$ & $18(5)$ & - & - & - \\
\hline 2 & $15(3)$ & $18(2)$ & $28(3)^{*}$ & $0.19(0.17)$ & $0.17(0.06)$ & $0.24(0.10)$ \\
\hline 5 & $19(3)$ & $16(1)$ & $26(5)^{*}$ & $0.13(0.11)$ & $0.21(0.08)$ & $0.22(0.12)$ \\
\hline 10 & $19(2)$ & 17 (4) & $22(5)$ & $0.23(0.11)$ & $0.28(0.08)$ & $0.24(0.11)$ \\
\hline 20 & $17(3)$ & $13(2)$ & $20(4)$ & $0.13(0.12)$ & $0.18(0.06)$ & $0.23(0.08)$ \\
\hline 30 & $19(3)$ & $14(2)$ & $16(3)$ & $0.22(0.15)$ & $0.21(0.05)$ & $0.20(0.07)$ \\
\hline 40 & $20(2)$ & $16(6)$ & $15(3)$ & $0.02(0.10)$ & $0.16(0.05)$ & $0.28(0.08)$ \\
\hline 50 & $20(5)$ & $15(2)$ & $17(5)$ & $0.10(0.15)$ & $0.19(0.06)$ & $0.22(0.13)$ \\
\hline 60 & $15(3)$ & $17(5)$ & $17(4)$ & $0.20(0.10)$ & $0.21(0.07)$ & $0.22(0.12)$ \\
\hline Salbutamol & - & - & - & $1.05(0.20)$ & $1.05(0.20)$ & $0.93(0.15)$ \\
\hline
\end{tabular}

$2.5 \mathrm{mg}$ nebulized salbutamol given at $60 \mathrm{~min}$ and $\mathrm{FEV}_{1}$ repeated 20 min later. ANP: atrial natriuretic peptide; FEV forced expiratory volume in one second. *: $\mathrm{p}<0.05$ (versus placebo).

\section{Results}

Study 1. No significant bronchodilatory effect was observed after inhalation with either dose of ANP (table 2). Mean (SEM) basal plasma levels of ANP were 17 (3) $\mathrm{pg} \cdot \mathrm{ml}^{-1}$ on the placebo day (normal $\leq 50 \mathrm{pg} \cdot \mathrm{ml}^{-1}$ ), and were not significantly different on either day of active inhalation. After inhalation of the $1 \mathrm{mg}$ dose ANP, there was a minimal transient elevation of circulating levels rising from $18(5) \mathrm{pg} \cdot \mathrm{ml}^{-1}$ basal to $28(3) \mathrm{pg} \cdot \mathrm{ml}^{-1}$ at 2 $\min (\mathrm{p}<0.01 v s$ placebo), but returning to normal thereafter (table 2).

Study 2. $\mathrm{FEV}_{1}$ rose significantly after ANP inhalation at both 2 and $5 \mathrm{~min}$, but was not significantly different from placebo from 10 min onwards (table 3 ). The maximal effect in $\triangle F E V_{1}$ was $0.42(0.09) l$, which was observed at $5 \mathrm{~min}$, but this was still less than $50 \%$ of the eventual response to inhaled salbutamol $(0.93(0.13) l$. Individual $\mathrm{FEV}_{1}$ results are presented in table 3. Basal plasma levels of ANP were comparable to those of Study 1, but after inhalation of ANP there was greater elevation of circulating peptide to $48(17) \mathrm{pg} \cdot \mathrm{ml}^{-1}$, peaking at $2 \mathrm{~min}$ and returning to normal by $10 \mathrm{~min}$ (table 3 ).

Table 3. - Study $2(n=5)$. Mean (SEM) plasma atrial natriuretic peptide (ANP) and $\triangle F E V_{1}$ in response to inhalation of $5 \mathrm{mg}$ ANP

\begin{tabular}{lcclcc}
\hline \multirow{2}{*}{$\begin{array}{c}\text { Time } \\
\text { min }\end{array}$} & \multicolumn{2}{c}{ Plasma ANP $\mathrm{pg} \cdot \mathrm{ml}^{-1}$} & & \multicolumn{2}{c}{$\Delta \mathrm{FEV}_{1} l$} \\
\cline { 2 - 3 } \cline { 5 - 6 } & Placebo & $5 \mathrm{mg}$ ANP & & Placebo & $5 \mathrm{mg}$ ANP \\
\hline Baseline & $19(3)$ & $15(4)$ & & - & - \\
2 & $18(5)$ & $48(17)^{*}$ & & $0.02(0.05)$ & $0.34(0.10)^{*}$ \\
5 & $13(5)$ & $40(13)^{*}$ & & $0.05(0.11)$ & $0.42(0.09)^{*}$ \\
10 & $15(3)$ & $27(6)$ & & $0.03(0.07)$ & $0.31(0.08)$ \\
20 & $20(4)$ & $20(3)$ & & $0.11(0.14)$ & $0.16(0.12)$ \\
30 & $21(5)$ & $19(2)$ & & $0.13(0.09)$ & $0.16(0.14)$ \\
40 & $17(3)$ & $13(3)$ & & $0.10(0.04)$ & $0.20(0.20)$ \\
50 & $19(3)$ & $16(6)$ & & $0.24(0.11)$ & $0.19(0.18)$ \\
60 & $19(5)$ & $15(4)$ & & $0.22(0.10)$ & $0.27(0.17)$ \\
Salbutamol & - & - & & $0.96(0.15)$ & $0.93(0.13)$ \\
\hline
\end{tabular}

$2.5 \mathrm{mg}$ nebulized salbutamol given at $60 \mathrm{~min}$ and $\mathrm{FEV}_{1}$ repeated 20 min later. For abbreviations see legend to table 2 . *: $\mathrm{p}<0.05$ (versus placebo).
No significant changes in pulse or blood pressure were found even following the highest dose of inhaled ANP, nor was there any change in circulating catecholamine levels.

There were no side-effects during active or placebo inhalation and no taste was attributed to ANP.

\section{Discussion}

This study is the first demonstration that high dose atrial natriuretic peptide has significant, albeit transient, bronchodilatory properties when given by inhalation, as demonstrated by the mean (SEM) 22 (5)\% increase in the $\mathrm{FEV}_{1}$ value from baseline measurements $15 \mathrm{~min}$ after the inhalation of $5 \mathrm{mg}$ ANP.

It is appropriate to ask why such a large quantity of ANP was required to produce bronchodilation when given by inhalation, and the answer is probably to be found in the way in which ANP is handled by the airway. Local inactivation of ANP in other physiological systems is twofold: enzymatic degradation by the $\mathrm{Zn}^{2+}$-metallopeptidase endopeptidase-24.11 (neutral endopeptidase or NEP); and inactivation following binding to a non-guanyl cyclase dependent "clearance" receptor [13]. The distribution of NEP in the human bronchial tree has not been extensively investigated, but significant NEP immunoreactivity has been demonstrated to exist in epithelium, submucosal glands, nerves and airway smooth muscle [14-16]. More recently, NEP mRNA has been shown to be expressed on cultured human bronchial smooth muscle cells [17], and it is likely that NEP exists in abundance in the airway. Very little is known about clearance receptors in the airway. A recent study demonstrated large numbers of ANP receptor sites on cultured tracheal smooth muscle cells, fibroblasts and glial cells, and most appeared to be of the non-guanyl cyclase coupled or clearance type [18].

It has, so far, been assumed that ANP achieves its effect by acting directly on airway smooth muscle. There is a body of evidence to support this in a number of animal models which have shown a dose-dependent relaxant effect of ANP or the atriopeptins (truncated forms of ANP) in guinea-pig [7, 19, 20] and bovine [21] tracheal preparations in vitro. It should be noted from these 
data, however, that lung parenchyma was very much less responsive than trachea [7], and that the response to ANP showed a degree of species dependence [7, 19]. Earlier studies using atriopeptins failed to show any significant relaxant effect on isolated human bronchial smooth muscle [22, 23], and, more recently CANDENAS et al. [24] have suggested that the 28 amino acid circulating form was also without significant effect. However, our own work has shown that ANP does have a direct relaxant effect in vitro, albeit at relatively high concentrations [25], and that the inhibition of phosphoramidon sensitive protease increases the effect of ANP on airway smooth muscle. These findings suggest that degradation of ANP by NEP in vivo would severely limit the bronchodilatory effect of ANP. High doses $(5 \mathrm{mg})$ of inhaled ANP may saturate this mechanism and so allow a bronchodilator effect to be seen.

If it is argued that the presence of NEP in the airway is the principal reason why inhaled ANP is ineffective in all but the highest inhaled dose, it is somewhat surprising that a transient elevation of plasma levels (indicating passage of unaltered peptide into the bronchopulmonary circulation) was detected after the $1 \mathrm{mg}$ inhalation. This apparent anomaly may simply be a consequence of our particular methodology in employing the Mizer aerosol conservation device, the efficiency of which results in an approximate doubling of the amount of aerosol delivered to the lungs compared to a conventional jet nebulizer [12]. This increased deposition is seen both centrally and peripherally. Peripherally-deposited aerosol is available for absorption and subsequent detection in peripheral blood, although peak plasma levels were 10-20 fold less than those required to produce bronchodilation in our previous study [4]. That the plasma levels should be elevated so transiently simply reflects the short half-life ( $\sim 3 \mathrm{~min})$ of circulating ANP [26].

Various inhibitors of NEP are available, and it might be expected that these would augment the beneficial effect of ANP in the airway. Unfortunately, NEP is not specific for ANP but also cleaves a number of bronchospastic peptides, such as substance $\mathrm{P}$, neurotensin and bradykinin. Whether the effect of NEP inhibition on airway function is advantageous or disadvantageous will, therefore, depends upon the relative contribution made by these various peptides.

In summary, we have demonstrated that ANP may produce significant bronchodilation when given by inhalation. Although the exact mode of action has yet to be clarified, there now exist several biochemical and pharmacological ways in which this effect might be augmented. We believe that this study provides further evidence to suggest that substances which stimulate guanyl cyclase and intracellular cGMP generation in the human airway warrant further investigation as potential bronchodilatory agents.

Acknowledgements: The authors wish to thank J. Doyle, J. Grant and M. Campbell for their help with hormone assays. The cost of ANP was met by a grant from the Chest, Heart and Stroke Association (Scotland). GH was supported by a Wellcome Medical Graduate Fellowship.

\section{References}

1. Ishii $Y$, Watanabe $T$, Watanabe $M$, Hasegawa $S$, Uchiyama Y. Effects of atrial natriuretic peptide on Type II epithelial cells of the rat lung. J Anat 1989; 166: 85-95.

2. Ishii $Y$, Watanabe T, Watanabe M, Hasegawa S, Uchiyama Y. Effects of atrial natriuretic peptide on Type II epithelial cells of the rat lung. J Anat 1989; 166: 85-95.

3. Obata K, Yasue H, Okumura K, et al. Atrial natriuretic polypeptide is removed by the lungs and released into the left atrium as well as the right atrium in humans. $J$ Am Coll Cardiol 1990; 15: 1537-1543.

4. Hulks G, Jardine A, Connell JMC, Thomson NC. Bronchodilator effect of atrial natriuretic peptide in asthma. Br Med J 1989; 229: 1081-1082.

5. Chanez $\mathrm{P}$, Mann $\mathrm{C}$, Bousquet J, et al. Atrial natriuretic factor (ANF) is a potent bronchodilator in asthma. $J$ Allergy Clin Immunol 1990; 86: 321-324.

6. Angus RM, McCallum MJA, Hulks G, Thomson NC. Bronchodilator, cardiovascular, and cyclic guanylyl monophosphate response to high-dose infused atrial natriuretic peptide in asthma. Am Rev Respir Dis 1993; 147: 1122-1125.

7. Hamel R, Ford-Hutchinson AW. Relaxant profile of synthetic atrial natriuretic factor on guinea-pig pulmonary tissues. Eur J Pharmacol 1986; 121: 151-155.

8. Hulks G, Thomson NC. Inhaled atrial natriuretic peptide and asthmatic airways. Br Med J 1992; 304: 1156.

9. Angus RM, McCallum MJA, Thomson NC. Effect of inhaled atrial natriuretic peptide in methacholine-induced bronchoconstriction in asthma. Clin Exp Allergy 1994; 24: in press.

10. Richards AM, Tonolo G, McIntyre GD, Leckie BJ, Robertson JIS. Radio-immunoassay for plasma alphahuman natriuretic peptide: a comparison of direct and pre-extracted methods. J Hypertension 1987; 5: 227-236.

11. Ball SG, Tree M, Morton JJ, Inglis GC, Fraser R. Circulating dopamine: its effects on plasma concentrations of catecholamines, renin, angiotensin, aldosterone and vasopressin in the conscious dog. Clin Sci 1981; 61: 417-422.

12. O'Doherty MJ, Thomas S, Page C, et al. Differences in relative efficiency of nebulisers for pentamidine administration. Lancet 1988; ii: 1283-1286.

13. Maack T, Suzuki M, Almeida FA, et al. Physiological role of silent receptors of atrial natriuretic factor. Science 1987; 238: 675-678.

14. Iwamoto I, Ueki IF, Borson DB, Nadel JA. Neutral endopeptidase modulates tachykinin-induced increase in vascular permeability in guinea-pig skin. Int Arch Allergy Appl Immunol 1989; 88: 288-293.

15. Skidgel RA, Engelbrecht A, Johnson AR, Erdös EG. Hydrolysis of substance $\mathrm{P}$ and neurotensin by converting enzyme and neutral endopeptidase. Peptides 1984; 5: 769-776.

16. Johnson AR, Ashton J, Schulz WW, Erdös EG. Neutral metalloendopeptidase in human lung tissue and cultured cells. Am Rev Respir Dis 1985; 132: 564-568.

17. Baraniuk JN, Mak J, Letarte M, Davies R, Twort C, Barnes PJ. neutral endopeptidase mRNA expression in airways. Am Rev Respir Dis 1991; 143: A40.

18. James S, Burnstock G. Atrial and brain natriuretic peptides share binding sites on cultured cells from the rat trachea. Cell Tissue Res 1991; 265: 555-565.

19. O'Donnell M, Garippa R, Welton AF. Relaxant activity of atriopeptins in isolated guinea-pig airway and vascular smooth muscle. Peptides 1985; 6: 597-601. 
20. Potvin W, Varma DR. Bronchodilator activity of atrial natriuretic peptide in guinea-pigs. Can J Physiol Pharmacol 1989; 67: 1213-1218.

21. Ishii K, Murad F. ANP relaxes bovine tracheal smooth muscle and increases cGMP. Am J Physiol 1989; 256 (Cell Physiol 25): C495-C500.

22. Labat C, Norel X, Benveniste J, Brink C. Vasorelaxant effects of atrial peptide II on isolated human pulmonary muscle preparations. Eur J Pharmacol 1988; 150: 397-400.

23. Fernandes LB, Preuss JMH, Goldie RG. Epithelial modulation of the relaxant activity of atriopeptides in rat and guinea-pig tracheal smooth muscle. Eur J Pharmacol 1991; 219: 187-194.
24. Candenas M-L. Naline E, Puybasset L, Deviller P, Advenier C. Effect of atria natriuretic peptide and of atriopeptins on the human isolated bronchus. Comparisons with the reactivity of the guinea-pig isolated trachea. Pulm Pharmacol 1991; 4: 120-125.

25. Angus RM, Nally JE, McCall R, Young LC, McGrath JC, Thomson NC. Modulation of the effect of atrial natriuretic peptide in human and bovine bronchi by phosphoramidon. Clin Sci 1994; 86: 291-295.

26. Yandle TG, Richards AM, Nicholls MG, Cuneo R, Espiner EA, Livesey JH. Metabolic clearance rate and plasma half-life of alpha-human atrial natriuretic peptide in man. Life Sci 1986; 38: 1827-1833. 